九州大学学術情報リポジトリ

Kyushu University Institutional Repository

\title{
Distribution and Spectrum Analysis of Noise on a Combine Harvester
}

\section{Inoue, $\mathrm{Eij \textrm {i }}$}

Laboratory of Agricultural machinery, Faculity of Agriculture, Kyushu University

Kinoshita, 0samu

Laboratory of Agricultural machinery, Faculity of Agriculture, Kyushu University

Kashima, Jun

Laboratory of Agricultural machinery, Faculity of Agriculture, Kyushu University

Sakai, Jun

Laboratory of Agricultural machinery, Faculity of Agriculture, Kyushu University

https://doi.org/10.5109/24046

出版情報：九州大学大学院農学研究院紀要. 38 (1/2)，pp.137-145，1993-12. Kyushu University バージョン：

権利関係 : 
J. Fac. Agr., Kyushu Univ., 38 (1•2), 137-145 (1993)

\title{
Distribution and Spectrum Analysis of Noise on a Combine Harvester
}

\author{
Eiji Inoue, Osamu Kinoshita, Jun Kashima \\ and Jun Sakai \\ Laboratory of Agricultural Machinery, Faculty of Agriculture, \\ Kyushu University 46-05, Fukuoka 812, Japan \\ (Received August 9, 1993)
}

\begin{abstract}
It is important to comprehend the characteristics of the noise occurring from combine harvesters in order to reduce the noise. In this study, estimation of noise at the operator's head, the measurement of noise distribution, and the spectrum analysis of noise at the operator's head were performed. As a result, at the operator's head, A-weighted sound pressure level was $87 \mathrm{~dB}(\mathrm{~A})$ in the time domain, and A-weighted sound pressure levels at $160 \mathrm{~Hz}$ and $330 \mathrm{~Hz}$ were $72 \mathrm{~dB}(\mathrm{~A})$ and $71 \mathrm{~dB}(\mathrm{~A})$ in the frequency domain. So the operator feels uncomfortable in this working environment. It was found through the measurement of noise distribution that many noise sources and forms of parts constituting a combine harvester characterized the distribution and levels of the noise occurring from a stationary combine harvester. It was found through the spectrum analysis of the noise at the operator's head that the engine exhaust would characterize the frequencies of the spectrum peaks of the noise at the operator's head.
\end{abstract}

\section{INTRODUCTION}

Noise occurring from agricultural machinery hurts human bodies. Noise sources have increased with machanization of agricultural work. However,optimum design considering noise reduction has not been achieved sufficiently. Therefore, effective countermeasures are required to realize a comfortable and useful working environment, prevention of accidents, and reduction of fatigue from the point of view of human engineering.

The object of this study is noise reduction on Japanese combine harvesters which have many noise sources and a harmful working environment. In this study, estimation of noise at the operator's head,, the measurement of noise distribution, and the spectrum analysis of noise at the operator's head were performed in order to comprehend the characteristics of noise occurring from a combine harvester.

These measurements were performed in a field without building within a radius of $100 \mathrm{~m}$ at the Kyushu University Farm, on fine and windless day. Background noise could be ignored, because it differed by $10 \mathrm{~dB}$ from object noise in the time and frequency domain. Specifications of the experimental combine harvester are shown in Table 1. 
Table 1. specifications of the experimental combine harvester.

\begin{tabular}{ll}
\hline Total width & $3.260 \mathrm{~m}$ \\
Total length & $1.680 \mathrm{~m}$ \\
Total height & $1.605 \mathrm{~m}$ \\
Total weight & $1075 \mathrm{~kg}$ \\
Engine exhaust & $669 \mathrm{cc}$ \\
Engine output & $10.30 \mathrm{~kW}$ \\
Engine Revolutions & $2700 \mathrm{rpm}$
\end{tabular}

\section{METHODS}

\section{M easurement of noise distribution}

The horizontal distribution of noise was measured at the operator's head, at a height of $1.8 \mathrm{~m}$, and the vertical distribution of noise was measured in the longitudinal plane, at the operator's position, on a stationary combine harvester. Both of the noise distributions were measured in order to comprehend the three-dimensional distribution, especially in the neighborhood of the operator's head.

Sound level meter (Rion NA-20) was used for the measurement. The dynamic characteristic sensitivity of the sound level meter was set to "FAST". Mean values of three replicates of measurements taken at each point were recorded as sound pressure level and A-weighted sound pressure level. The microphone was oriented towards the direction producing the maximum level.

Measuring points were divided into a mesh, composed of $0.5 \mathrm{~m}$ interval on the horizontal section and 0.2 or $0.25 \mathrm{~m}$ interval on the vertical section. However, areas with greatly declining sound levels were measured in finer mesh. The number of measuring points was 77 on both sections. Measuring conditions are as follows;

1) only engine working.

2) all working units (threshing section, reaping section, and cutter section) driven,reaping section set to 6th speed.

\section{Spectrum analysis of noise at the operator's head}

A combine harvester has many noise sources, because it has many working machines and has a complex structure. However, Miyazawa and Irie (1987) reported that noise sources could be identified in the frequency domain by the acoustical holography method. In this study, spectrum analysis of noise at the operator's head on a stationary and reaping combine harvester was performed in order to identify noise sources.

The sound level meter (Rion NA-20) and the data recorder (TEAC R-61) and the FFT analyzer (A\&D AD-3525) were used for this analysis. The sound level meter was placed at the operator's head. The experimental rice field conditions are shown in Table 2. The measuring conditions are as follows; 
Table 2. Experimental rice field conditions.

\begin{tabular}{ll}
\hline Cultivars & Hinohikari \\
Strips spacing & $0.300 \mathrm{~m}$ \\
plants spacing & $0.180 \mathrm{~m}$ \\
Trunk length & $0.826 \mathrm{~m}$ \\
Number of ears on a plant & 21 \\
Number of grains on a plant & 74.6 \\
Harvested quantity & $0.825 \mathrm{~kg} / \mathrm{m}^{2}$ \\
\hline
\end{tabular}

[Measuring conditions on a stationary combine harvester]

1) Only engine working.

2) Threshing section and cutter driven.

3) All working units (threshing section, reaping section, and cutter section) driven, reaping section set to 2 nd speed.

4) All working units (threshing section, reaping section, and cutter section) driven, reaping section set to 4 th speed.

5) All working unit (threshing section, reaping section, and cutter section) driven, reaping section set to 6th speed.

[Measuring conditions on a reaping combine harvester]

6) Traveling velocity set to $0.28 \mathrm{~m} / \mathrm{s}$.

7) Traveling velocity set to $0.36 \mathrm{~m} / \mathrm{s}$.

8) Traveling velocity set to $0.46 \mathrm{~m} / \mathrm{s}$.

\section{RESULTS AND DISCUSSIONS}

\section{Estimation of noise at the operator's head}

A-weighted sound pressure level in the time domain at the operator's head was $87 \mathrm{~dB}(\mathrm{~A})$. In this working environment, the operator must shout to converse (Ohshima, 1972). In addition, since the level causing deafnesss is $90 \mathrm{~dB}(\mathrm{~A})$ in the time domain (Nakano, 1990), the noise occurring from the combine harvester doesn't deafen the operator.

The spectrum of A-weighted sound pressure level at the operator's head is shown in Fig. 1. The levels at both $160 \mathrm{~Hz}$ and $330 \mathrm{~Hz}$ are highest. In this working environment, loudness reaches about only $0.3 \sim 0.6 \mathrm{~m}$, telephoning becomes difficult, and the operator feels uncomfortable (Morgan et al., 1972).

Therefore, this working environment must be improved.

\section{M easurements of noise distribution}

The horizontal distribution of A-weighted sound pressure level is shown in Fig. 2 and Fig. 3. The horizontal distribution of sound pressure level is shown in Fig. 4 and Fig. 5. The vertical destribution of sound pressure level is shown in Fig. 6 and Fig. 7. Since the horizontal distribution of A-weighted sound pressure level is greatly different from that of sound pressure level, both of the results are shown in order to compare.

When the threshing section is driven, the sound levels above the threshing section 


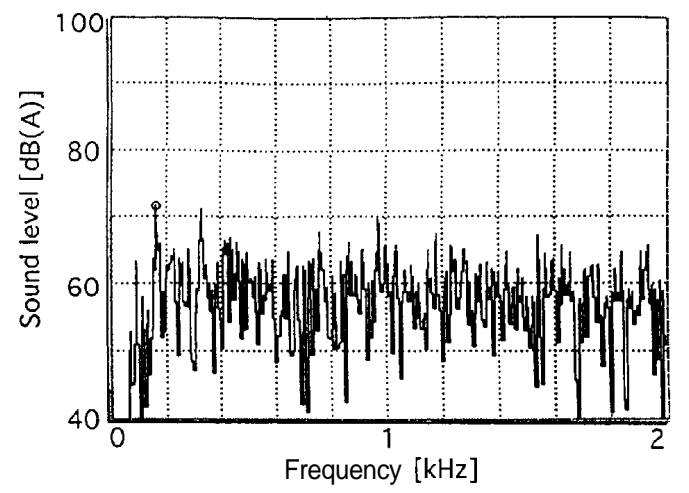

Fig. 1. Spectrum of A-weighted sound pressure level at the operator's head on a reaping combine harvester; traveling velocity set to $0.46 \mathrm{~m} / \mathrm{s}$.

become high. The levels on the right side of the combine harvester are comparatively higher, because the noise radiated from the forward directed air intake of the engine cooling fan influenced this area. The area on the left back side of the operator has low levels on the horizontal distribution of A-weighted sound pressure level, because the levels in the range of frequency from $500 \mathrm{~Hz}$ to $8 \mathrm{kHz}$ are reduced.

The vertical distribution of sound pressure level indicates that the levels above the hopper are much reduced due to the form and position of the hopper. When the cutter is driven, low position distribution on the rear of the combine harvester changes and levels increase.

After all, the layout of each section, selection of forms, and materials of the parts would characterize noise distribution and levels. However, noise sources must be identified for noise reduction, so the acoustical intensity method or the acoustical holography method will be suitable.

\section{Spectrum analysis of noise at the operator's head}

The spectrum peaks are concentrated in the range of frequency from $0 \mathrm{~Hz}$ to $500 \mathrm{~Hz}$ under all measuring conditions as shown in Fig. 8 to Fig. 15. When the working units are driven,the levels at $160 \mathrm{~Hz}$ are higher and the levels at $270 \mathrm{~Hz}$ are lower. When the combine harvester reaps fields, the levels at $90 \mathrm{~Hz}$ are lower. The frequencies of spectrum peaks are constant as a whole. Moreover, each frequency is a multiple of $22.5 \mathrm{~Hz}$.

Now, frequencies of infrasound radiating from the engine exhaust are given by the following equation (Nakano 1990).

$$
f=\frac{R m}{60 k} \mathrm{~Hz}(m=1,2,3, \cdots)
$$

where $R$ :Engine revolutions $(\mathrm{rpm})$

$k: k=1$ in case of a 2 cycle engine, $k=2$ in case of a 4 cycle engine

When this equation is applied to the above results, the frequencies become $22.5,45.0$, $67.5,90.0,112.5,135.0, \cdots \mathrm{Hz}$. These frequencies correspond to almost all spectrum peaks 


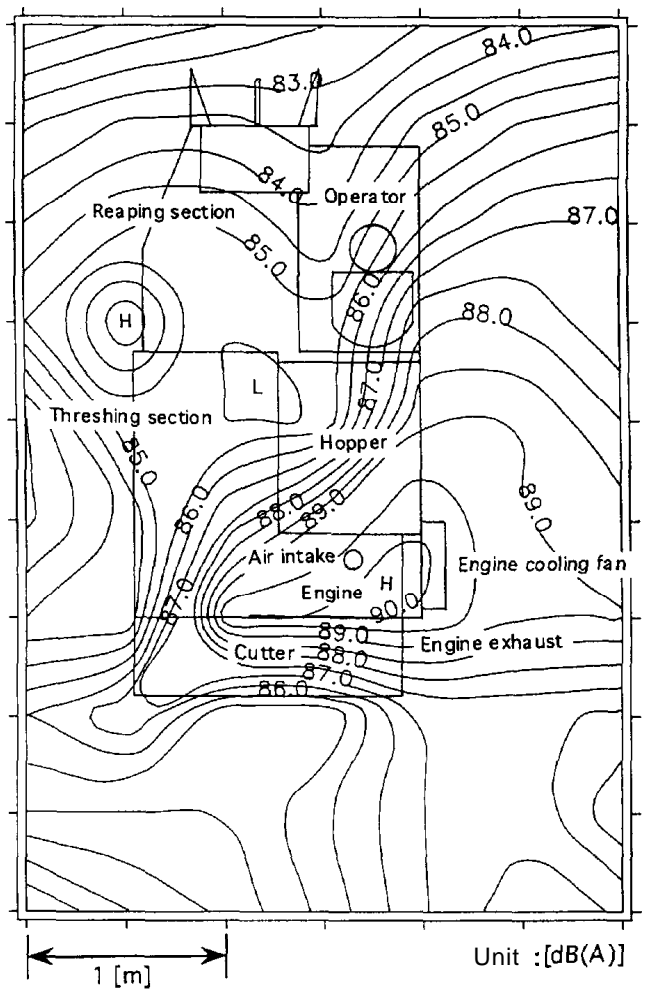

Fig. 2. Horizontal distribution of A-weighted sound pressure level at the operator's head, at a height of $1.8 \mathrm{~m}$, on a stationary combine harvester; only engine working.

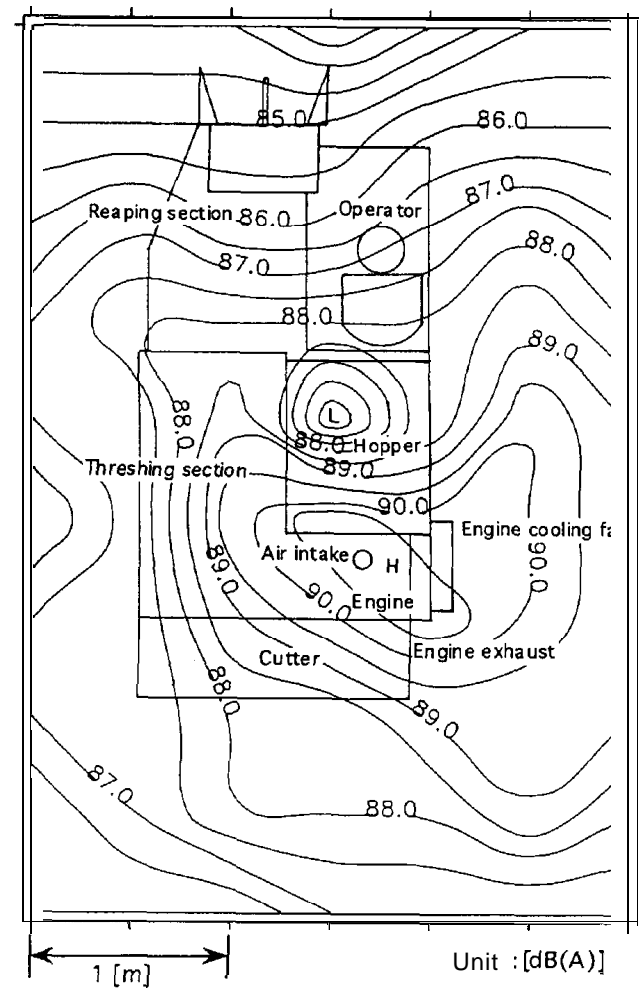

Fig. 3. Horizontal distribution of A-weighted sound pressure level at the operator's head, at a height of $1.8 \mathrm{~m}$, on a stationary combine harvester; all working units driven, reaping section set to 6th speed.

illustrated in Fig. 8 to Fig. 15. Therefore, the engine exhaust would characterize the frequencies of the spectrum peaks. However, the peaks at $166 \mathrm{~Hz}$ which have comparatively high levels don't correspond. Therefore, it is considered that the peaks may not be influenced by the engine exhaust. However, this equation is usually applied to infrasound radiating from the engine exhaust, so this consideration must be examined further.

In future, noise sources must be identified. Moreover, noise source contributions must be analyzed.

\section{ACKNOWLEDGEMENTS}

We wish to thank Mr.Moses Frank Oduori for assistance with the English form of the manuscript. 


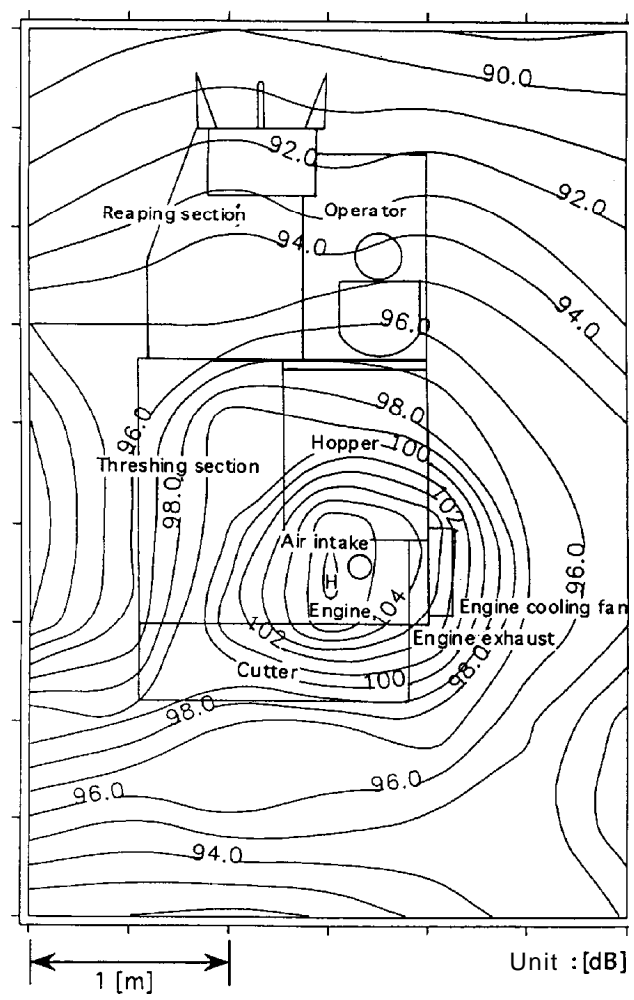

Fig. 4. Horizontal distribution of sound pressure level at the operator's head, at a height of $1.8 \mathrm{~m}$, on a stationary combine harvester; only engine working.

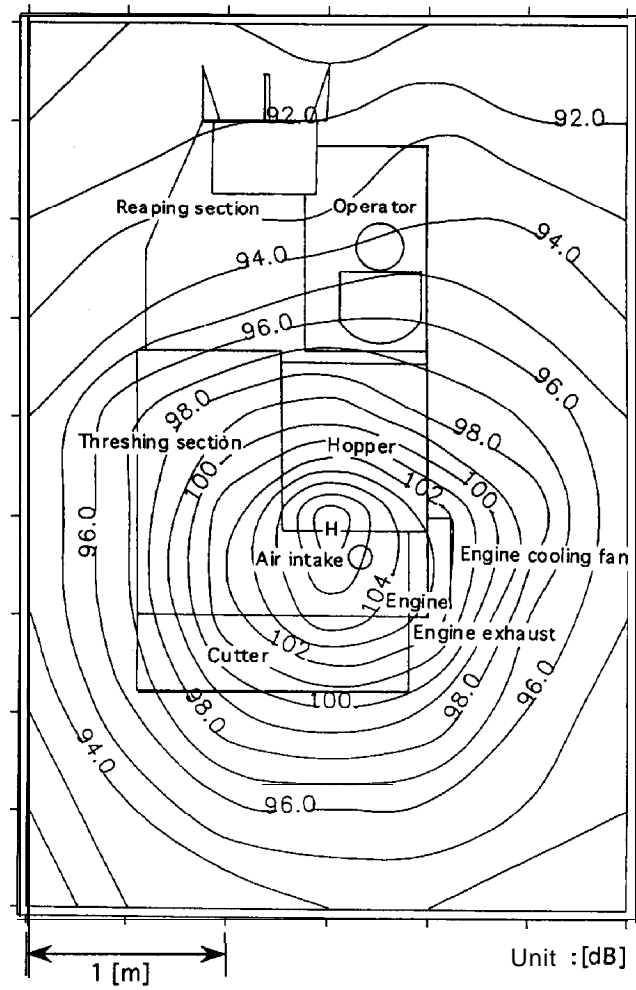

Fig. 5. Horizontal distribution of sound pressure level at the operator's head, at a height of $1.8 \mathrm{~m}$, on a stationary combine harvester; all working units driven, reaping section set to 6 th speed.

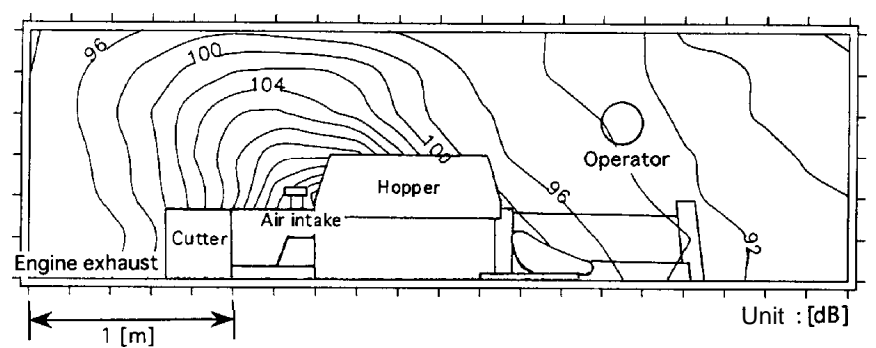

Fig. 6. Vertical distribution of sound pressure level in the longitudinal plane, at the operator's position on a stationary combine harvester; only engine working. 


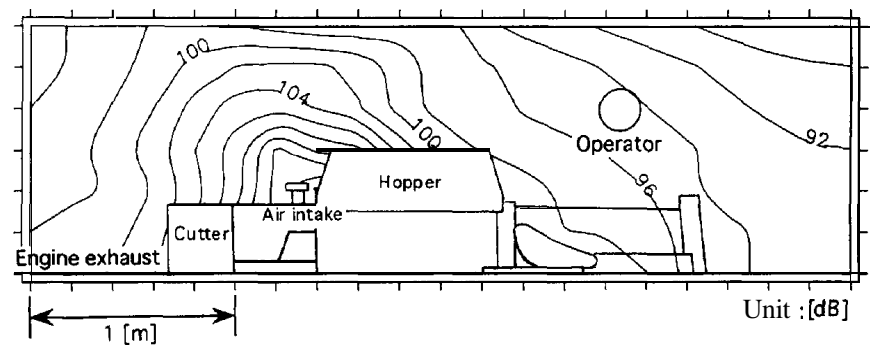

Fig. 7. Vertical distribution of sound pressure level in the longitudinal plane, at the operator's position on a stationary combine harvester; all working units driven, reaping section set to 6 th speed.

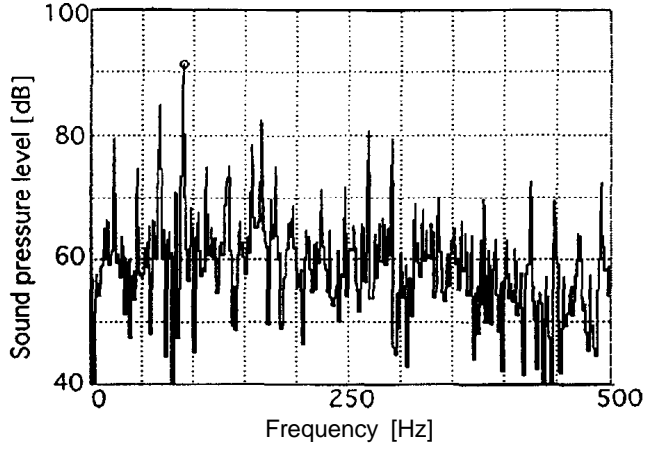

Fig. 8. Spectrum of sound pressure level at the operator's head on a stationary combine harvester, only engine working.

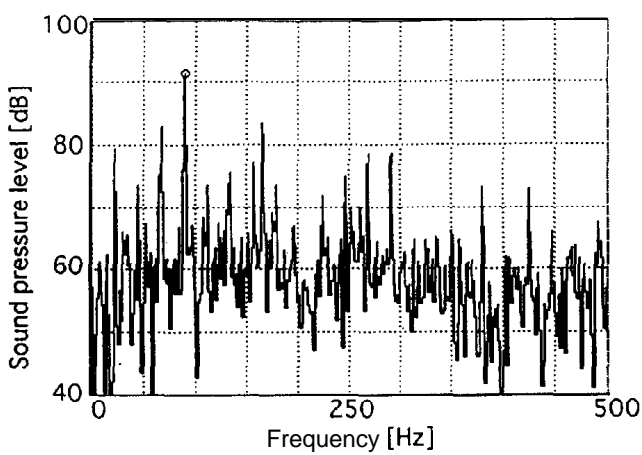

Fig. 10. Spectrum of sound pressure level at the operator's head on a stationary combine harvester; all working units driven, reaping section set to 2 nd speed.

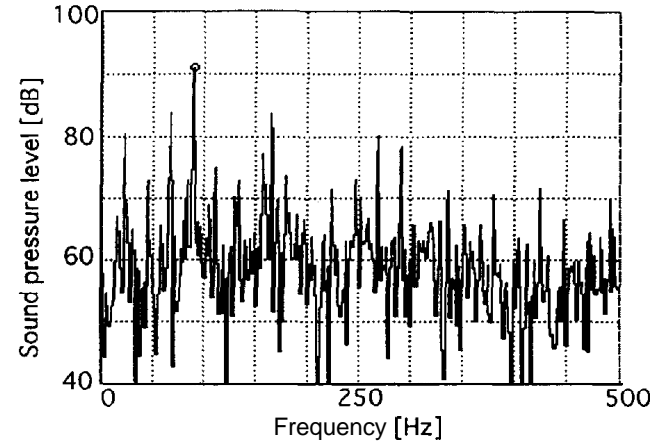

Fig. 9. Spectrum of sound pressure level at the operator's head on a stationary combine harvester; threshing section and cutter driven.

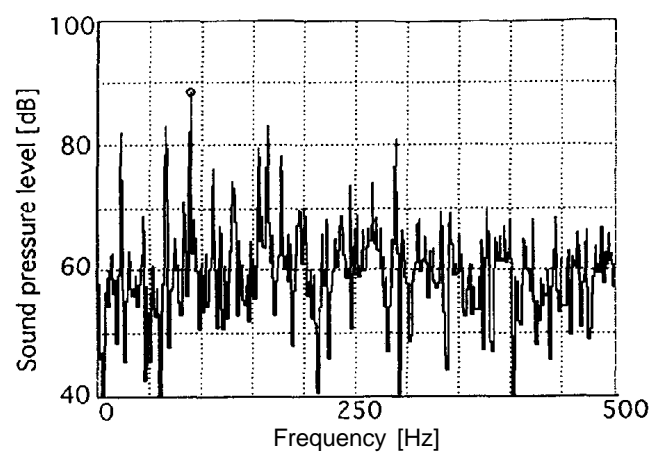

Fig. 11. Spectrum of sound pressure level at the operator's head on a stationary combine harvester; all working units driven, reaping section set to and speed. 


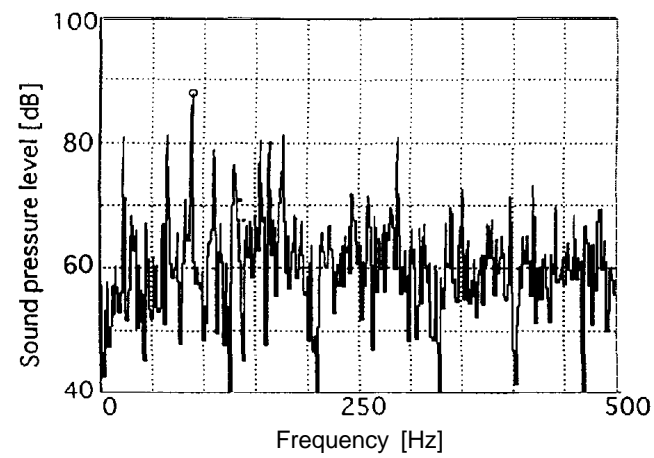

Fig. 12. Spectrum of sound pressure level at the operator's head on a stationary combine harvester;all working units driven, reaping section set to 6 nd speed.

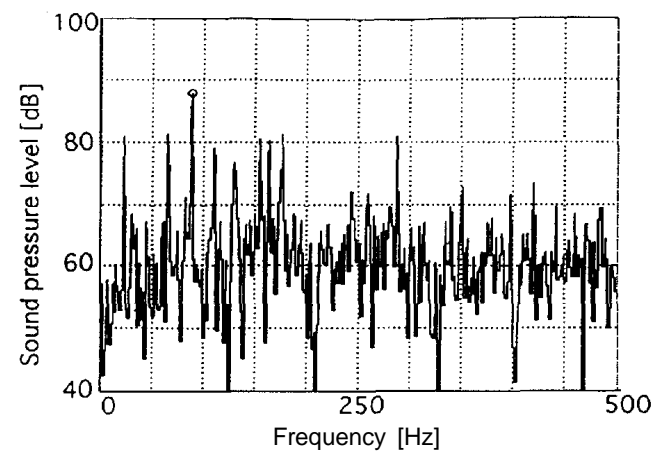

Fig. 14. Spectrum of sound pressure level at the operator's head on a reaping combine harvester; all working units driven, traveling velocity set to $0.36 \mathrm{~m} / \mathrm{s}$.

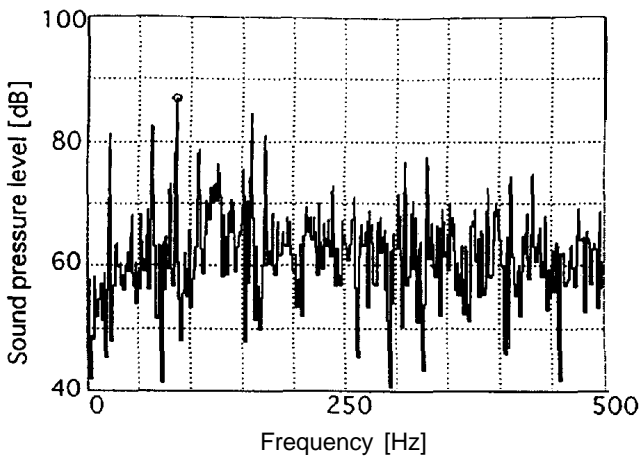

Fig. 13. Spectrum of sound pressure level at the operator's head on a reaping combine harvester; all working units driven, traveling velocity set to $0.28 \mathrm{~m} / \mathrm{s}$.

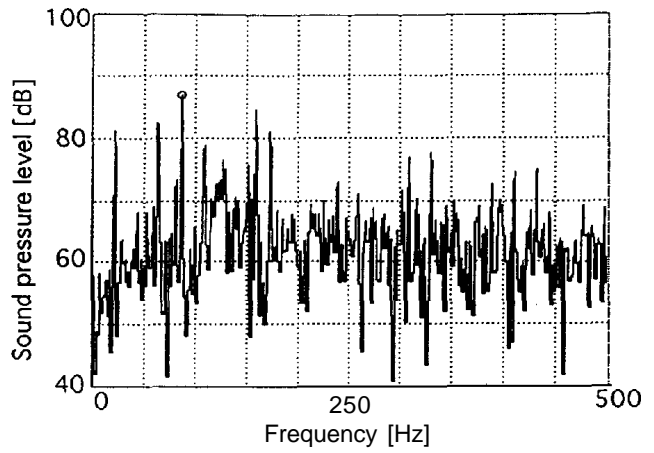

Fig. 15. Spectrum of sound pressure level at the operator's head on a reaping combine harvester; all working units driven, traveling velocity set to $0.46 \mathrm{~m} / \mathrm{s}$.

\section{REFERENCES}

Hayashi, T., T. Ohwa and Y. Nogiwa 1981 Detection of sound on the Bases of Acousitical Holography. Tohsiba Review, Japan, 36 (3): 237-240

Ichimiya, R. 1992 Acoustical Engineering. Corona Publishing, Japan

Kanda, K., Y. Irie, H. Nakagawa, H. Ishikawa and K. Yamamoto 1983 Noise Reduction of High Speed Direct Injection Diesel Engine. Technical Reports of Mitsubishi Heavy Industries, Japan, $20(5): 1-10$

Kojirai, T. 1984 Measurement by Acoustical Intensity Method. Technical Materials of Rion, 408, Japan

Miyazawa, N. and Y. Irie 1987 Noise Analysis of Small Combine. Inter Noise 78: 401-404

Mogan, C.T., J. S. Cook, A. Chapanis, and M.W. Lund 1972 Human Engineering Guide to 
Equipment Design. Transl. by T. Kondoh et al., Corona Publishing, Japan, pp. 101-130, 399-409 Nakano, A. 1990 Techinique of noise and vibration. Toyodoh Publishing, Japan, pp. 186

Nishimura, M. 1984 Basis and Application of Acoustical Intensity Method. Technical Materials of Rion, 407, Japan

Oshima, M. 1972 Human Engineering. Corona Publishing, Japan, pp. 237-239

Oka, R., H. Akashi and K. Yamamoto 1978 Detection of Sound Sources on the Basis of Acoustical Holography. The Acoustical Society of Japan: I-4

Ueha, S. 1977 Acoustical Holography and Detection of Sound Sources. Journal of the Society of Instrument and Control Engineerings, Japan, 6 (5): 427-433

Ueha, S. 1982 Acoustical Holography. Journal of the Acoustical Society of Japan, 38 (3) : 166-169 